\title{
Role of Triphala Kwatha Gandusha in the management of Aphthous ulcer: A review study
}

\author{
Review Article
}

\section{Queency Evangaline Sutnga1*, Savita S Angadi², Innocent Sutnga ${ }^{3}$}

\author{
1. PG Scholar, 2. Professor and HOD, Department of Shalakya Tantra, \\ KAHER'S Shri. B. M. Kankanawadi Ayurveda Mahavidyalaya, Shahapur, Belagavi, Karnataka, India.
}

3. Department of Pharmaceutical Sciences, Dibrugarh University, Dibrugarh, Assam, India.

\begin{abstract}
Mukhapaka (Stomatitis) is a common ailment seen in general practice. The Pittaja Mukhapaka (Aphthous ulcer) is fully described in Ayurveda under the term Mukha rogas. Oral ulcers are estimated to impact $4 \%$ of the global population, with aphthous ulcers being the most frequent, affecting up to $25 \%$ of the global population. Psychological stress, hormonal impacts, dietary sensitivity, and nutritional insufficiency are the primary causes of Pittaja Mukhapaka (Aphthous ulcer). It is a painful and frequently recurring inflammatory disorder of the oral mucosa that can develop as a result of several well-defined disease processes. As a result, Gandusha is described as one of the key therapies in the Ayurvedic system of medicine for both preventing and treating oral cavity illnesses. Triphala (tri means three and phala means fruits) is an Ayurvedic preparation made up of three equal parts of Indian subcontinent herbal fruits: Terminalia belerica, Phyllanthus emblica, and Terminalia chebula. Triphala includes powerful antioxidants as well as other bioactive substances such as flavonoids, saponins, anthraquinones, amino acids, fatty acids, and different carbohydrates. As a result, it promotes the maintenance and promotion of oral hygiene by exerting a cleansing activity and strengthening the defence mechanism in the oral cavity. An attempt is made in this regard to discuss the role of Triphala Kwatha Gandusha in Pittaja Mukhapaka.
\end{abstract}

Key Words: Triphala Kwatha Gandusha, Pittaja Mukhapaka, Aphthous ulcer, Terminalia belerica, Phyllanthus emblica, Terminalia chebula.

\section{Introduction}

The ailments of the mouth cavity are referred to as Mukha rogas in Ayurveda. Ancient literature identifies "Mukha" as an organ consisting of dantamoola (gums), osta (lips), jihwa (Tongue), talu (palate), danta (Teeth), and gala (throat) (1). According to Astanga Hrudaya, Pittaja Mukhapaka (Aphthous ulcer) is one of the Mukha rogas diseases that can be interchanged with Aphthous ulcer due to comparable characteristic traits. The vitiated pitta dosha produces inflammation and ulceration of the oral mucosa, resulting in little reddish-yellow papules that grow in any location of the mouth, causing acute burning pain, altered taste, trouble masticating, and deglutition (2). Aphthous ulcers, which typically originate on the nonkeratinized oral mucosa, can be excruciatingly painful and can impair eating, speaking, and swallowing. RAS are classed as tiny $(1 \mathrm{~cm}$ in size) ulcers that heal quickly and without scarring and major $(>1 \mathrm{~cm}$ in size) ulcers that take

* Corresponding Author:

\section{Queency Evangaline Sutnga}

PG Scholar, Department of Shalakya Tantra,

KAHER'S Shri. B. M. Kankanawadi Ayurveda

Mahavidyalaya, Shahapur,

Belagavi, Karnataka. India.

Email Id: queencysutnga@gmail.com longer to heal and frequently scar. Herpetiform ulcers are the third type, and they appear as repeated crops of dozens of tiny lesions throughout the mucous membranes (3). Psychological stress, heredity, trauma, tobacco, inflammatory bowel disease, B-complex, vitamin, and folate deficiency, microbial causes, hormonal changes, and immunologic factors may all contribute to the development of ulcers (4). The clinician may run a blood test to rule out iron, vitamin $\mathrm{B}_{12}$, or folate deficiencies, as well as a full blood count, regularly. If a hematinic deficit is present, elimination diets or dietary supplementation may entirely alleviate symptoms. Thus, Gandusha is explained as one of the treatments to avoid or treat Mukha rogas disorder in Ayurveda to safeguard or treat the disorder of the mouth cavity. Depending on the severity of the sickness and the desired therapeutic results, various medicated liquids or decoctions can be used. The classics textbook lists a variety of yogas for Gandoosha/Kavala. Triphala is a well-known Ayurvedic medicinal constituent. It is regarded as the greatest and most flexible herbal formulation in India. The majority of Mukha rogas are kapha rakta pradhana rogas, whereas Triphala is kapha pitta hara dravya. As a result, Gandusha combined with Triphala kashaya will accelerate the healing process in Pittaja Mukhapaka (1). This paper presents a review of the important role of Triphala Kwatha Gandusha in Pittaja Mukhapaka. 
Three important dried fruits of the herbs combined from Ayurveda

1. In Shalakya Tantra tradition, Amla or Amlaki, also known as Indian Gooseberry (Emblica officinalis Family Euphorbiaceae), is considered auspicious.

2. Harad or haritaki, also known as Myrobylan (Terminalia chebula - Family Combretaceae).

3. Baheda or Vibhitaki, also known as Belliric myrobalan (Terminalia bellirica - Family Combretaceae).

Triphala's rasa or flavour is sweet, sour, pungent, bitter, and astringent; the only flavour not included in the recipe is salty. The formula's virya, or potency and action, is neutral, and its vipaka, or postdigestive impact, is sweet. Triphala is rich in prabhava, which helps to balance all doshas and constitutions. Amalaki's gunas are guru and ruksa, and Haritaki and Bhibitaki are both regarded laghu and ruksha (5).

\section{Possible Mode of Action of Triphala Kwatha Gandusha}

Gandusha is the oral administration of medications in which the active elements and chemical constituents of the drugs are absorbed through the buccal mucosa and enter the bloodstream (6). Gandusha raises the mechanical pressure inside the oral cavity, activates the salivary glands, enhances vascular permeability, and keeps the oral $\mathrm{pH}$ stable (6). The tannins, gallic acid, ellagic acid, and chebulinic acid are the formula's main ingredients, and they are all powerful antioxidants. Triphala also contains different carbohydrates, flavonoids (such as quercetin and luteolin), saponins, amino acids, fatty acids, and anthraquinones (5). The active ingredients in the medicine stimulate the parasympathetic fibres of the salivary gland, causing a significant amount of water to be released in the saliva. Parasympathetic fibres stimulate acetylcholine, acinar cells and widen salivary gland blood vessels. When sympathetic fibres are stimulated, saliva is secreted, which is viscous and rich in organic elements such as mucus. These fibres stimulate the nor-adrenaline system, acinar cells, and produce vasoconstriction (7). Furthermore, saliva inhibits bacterial growth by eliminating components that serve as bacterial culture media, proline-rich proteins contained in saliva that have anti-microbial properties, and immunoglobulin Ig in saliva that has antibacterial and anti-viral action (1).

\section{Phytoconstituents of Triphala Tannins}

Tannins are a broad term for a family of polymeric phenolic compounds with complex structures in plants that can tan leather or precipitate gelatin from solution, a trait known as astringency. Tannins are widely dispersed, accounting for 5 to $10 \%$ of dry vascular plant components and found primarily in bark, stems, seeds, roots, buds, and leaves. Tannins can also be found in foods such as grapes, blackberries, strawberries, walnuts, cashew nuts, hazelnuts, mangoes, and tea, among others (8). Their architectures divide them into three groups: hydrolysable tannins, condensed tannins, and complex tannins. The term "hydrolysable tannins" refers to a class of chemicals generated by phenolic acids and their derivatives via glycoside or ester linkages with glucose or polyols. They are further classified as gallotannins, which include solely galloyl groups, ellagitannins, which contain hexahydroxydiphenoyl group(s), and hydrolysable tannin oligomers, which are classified as dimers, trimers, and tetramers based on the number of glucose nuclei. Condensed tannins are a type of chemical that results from the carbon-carbon bond polymerization of flavane-3-ols like catechins or their derivative gallocatechin. Complex tannins are a family of molecules that are partially linked by carbon-carbon bonds and are composed of flavane-3-ol, the unit of condensed tannins and hydrolyzed tannins (9). Tannins are found in many plants and are thought to be defence chemicals that protect plant tissues against herbivorous attacks due to their astringent taste. This class of chemicals, particularly green teas and red wines, has gotten a lot of attention in recent years because of their ability to heal or prevent a variety of diseases. Tannins have been connected to several human physiological activities, including phagocytic cell activation, hostmediated tumour activity, and a broad range of antiinfective properties. They create complexes with proteins through non-specific forces such as hydrogen bonding and hydrophobic effects, as well as covalent bond formation, as one of their molecular functions $(10,11)$. As a result, their ability to inactivate microbial adhesins, enzymes, and cell envelope transport proteins may be related to their antimicrobial action mechanism (12). Several natural tannins and related compounds have been shown to have biological activities such as antioxidant, anticancer, hypolipidemic, hypoglycemic, and antibacterial properties (13).

\section{Quinones}

Quinones are a class of natural and manmade chemicals with a variety of therapeutic properties. Quinones are electron carriers that participate in photosynthesis. Like vitamins, they are a type of chemical that can help prevent and treat a variety of disorders, including osteoporosis and cardiovascular disease (14). Quinones are aromatic rings with two ketone substitutes. They're everywhere, and they're quick to react. The individual redox potential of the quinine-hydroquinone duo is crucial in many biological activities. Vitamin $\mathrm{K}$ is a naphthoquinone antihemorrhagic substance (15). Quinones have been shown to permanently interact with nucleophilic amino acids in proteins, resulting in protein inactivation and loss of function, as well as providing a source of persistent free radicals. As a result, the potential spectrum of quinone antibacterial activities is broad. In the microbial cell, surface-exposed adhesins, cell wall polypeptides, and other surface-exposed adhesins could be targets. Quinones can also prevent bacteria from accessing substrates (7). Quinones boost overall health due to their antioxidant activity. Many of the cancer treatments that have been authorised or are now in clinical development are quinone-related chemicals. Quinones 
are toxicologically active due to their occurrence as photoproducts of air pollution. Quinones are redox cycling compounds that can connect to thiol, amine, and hydroxyl groups (16).

\section{Flavones, flavonoids, and flavonols}

Polyphenolic flavonoids are among a large range of phytochemicals with one carbonyl group found in the human diet (as opposed to the two carbonyls in quinones). The inclusion of the 3-hydroxyl group results in the formation of the flavonol. Flavonoids are hydroxylated phenolic compounds as well, but they have a C6-C3 unit linked to an aromatic ring (17). Flavonoid consumption may reduce the risk of various age-related chronic diseases, according to preliminary research, animal models, and human trials. A large number of flavonoids and mixes of their subclasses, such as flavonols, flavones, and flavanones, as well as the variety of agricultural techniques that affect their concentration in foods, have made developing comprehensive food composition databases for these chemicals difficult (18). Nonetheless, dietary assessments have been used in cohort and case-control epidemiological studies, and several of them show an inverse association with the incidence of certain types of cancer, cardiovascular disease, and other chronic illnesses. Because they are known to be produced by plants in response to microbial infection, it is not surprising that they have been demonstrated in vitro to be effective anti-microbial chemicals against a wide variety of microorganisms. Their ability to form complexes with extracellular and soluble proteins, as well as bacterial cell walls, is most likely responsible for their activity. Microbial membranes may be harmed by high lipophilic flavonoids (19). These compounds have been shown to inhibit Vibrio cholerae, Shigella, and Streptococcus mutans in vitro. Inhibition of isolated bacterial glucosyltransferases in Streptococcus mutans, as well as a $40 \%$ reduction in fissure caries, has also been reported (12).

\section{Gallic acid}

Gallic acid is a commonly found phytoconstituent in all three Triphala plants. Gallic acid is a polyphenolic component found naturally in processed beverages such as red wines and green teas. It is found in plants as free acids, esters, catechin derivatives, and hydrolysable tannins (20). The pharmacological activity of these compounds as radical scavengers has piqued the curiosity of researchers (21). It has been shown to have potential preventive and therapeutic effects in many conditions where oxidative stress has been implicated, including cardiovascular disease, cancer cell growth inhibition, hepatoprotection, neurological disorders, and ageing (22). Gallic acid has been reported to occur in several plants, some of them are Allan blackia floribunda, Garcinia densivenia, Bridelia micrantha, Caesalpinia sappan, Dillenia indica, Diospyros cinnabarina, Paratecoma peroba, Terminalia bellerica, etc (7).

\section{Ascorbic acid}

Vitamin C, or ascorbic acid, is an essential dietary component for a variety of human biological functions, albeit its function at the cellular level is not obvious. Vitamin C is needed for collagen synthesis, the protein that fulfils so many connective roles in the body (23). It is essential in the manufacture of collagen under physiological conditions by promoting the hydroxylation of proline and lysine residues, permitting correct intracellular folding of pro-collagen for export and deposition as mature collagen. The framework of bone, gums, and binding materials in skin, muscle, or scar tissue are all collagen-containing components and structures in the body (24). In humans, vitamin $\mathrm{C}$ also functions as a cofactor in several essential hydroxylation events, including the production of catecholamines (through the conversion of dopamine to norepinephrine), L-carnitine, cholesterol, amino acids, and certain peptide hormones. Vitamin $\mathrm{C}$ is required to produce certain hormones and neurotransmitters, as well as the metabolism of various amino acids and vitamins. Scurvy is caused by a shortage of vitamin C, a pathological condition that causes blood vessel fragility and connective tissue damage due to a failure to produce collagen, and, eventually, death as a result of a total collapse. As an antioxidant, it reduces inflammatory symptoms by reacting with molecules such as histamines and peroxides (25). Its antioxidant properties have been linked to a reduction in cancer incidence and the prevention of cardiovascular disease. This vitamin also aids the liver in the detoxification of toxins in the body, as well as the blood in combating infections. Furthermore, the effects of vitamin $\mathrm{C}$ on the neurological system and chronically unwell patients have been reported. Because of the health benefits of vitamin $\mathrm{C}$, people are lured to consume too much of it. Adults' vitamin $\mathrm{C}$ requirements do not appear to be consistent across cultures. Minimal increases in blood vitamin $C$ levels reduce the chance of death from this disease (26). The fruit juice of Emblica officinalis has the most vitamin C concentration $(478.56 \mathrm{mg} / 100 \mathrm{~mL}$ ). When combined with other fruits, the fruit improved its nutritional quality in terms of vitamin $\mathrm{C}$ content. In $E$. officinalis, vitamin $\mathrm{C}$ accounts for $45-70 \%$ of the antioxidant action. The combination of vitamin $\mathrm{C}$ and bioflavonoid aids in the healing process (12).

\section{Applications \\ The Potential of Triphala in Oral Care}

Triphala has traditionally been utilised as an antimicrobial agent in Ayurvedic treatment. Triphala has been shown in numerous controlled clinical experiments to greatly reduce the number of oral bacteria, dental plaque, and gingivitis in human subjects. Triphala contains a high concentration of polyphenols and tannins. Triphala's polyphenolic content is responsible for its antioxidant and radioprotection potential by converting reactive oxygen free radicals to non-reactive products (27). Triphala effectively reduces oxidative damage caused by cold stress. Lipid peroxidation (LPO), enzymatic superoxide dismutase (SOD), catalase (CAT), non-enzymatic 
(Vitamin C) antioxidation status, and other parameters are used to assess cold-stress-induced oxidative stress. Triphala components significantly suppress Y-radiationinduced strand break development in plasmid DNA. They can scavenge free radicals such as DPPH and superoxide and prevent radiation-induced lipid peroxidation. Instead of using separate substances, the Triphala combination is more effective because it contains the combined activity of all three. Triphala's superoxide radical scavenging activity with xanthine and xanthine oxidase activity demonstrated that, in addition to reacting with superoxide radicals, Triphala suppressed uric acid production. Triphala contains a lot of phenols, polyphenols, and tannins. HPLC analysis revealed the presence of gallic acid. The antioxidant activity was assessed using the 1, 1-diphenyl-2picrylhydrazyl (DPPH) technique, as well as the prevention of lipid peroxide generation caused by the $\mathrm{Fe}^{2+}$ ascorbate system. They were discovered to have a high correlation with total polyphenol concentration. Antioxidant activity has been observed for mallotusinin and mucic acid 1, 4-lactone 3-Ogallate. Triphala is an effective scavenger of hydroxyl and nitric oxide radicals and has been shown to increase the capacity of experimental animals to withstand non-specific stress $(5,28)$.

\section{Triphala against stress}

Triphala supplementation has been shown to alleviate stress. Triphala treatment for 48 days can prevent cold stress-induced behavioural and biochemical abnormalities such as an increase in immobilisation, with an increase in rearing, grooming, and ambulation activity, as well as a significant increase in lipid oxidation (LPO) and corticosterone levels (29). Triphala protects rats from noise-induced alterations in the antioxidant and cell-mediated immune response (5).

\section{Triphala in Wound healing}

The granulation tissue has a lower bacterial population and higher levels of collagen, hexosamine, and uronic acid. When collagen sponges infused with Triphala were used to treat wounds, they demonstrated higher thermal stability, water uptake capabilities, faster wound closure, improved tissue regeneration, and other benefits. The combination of epigallocatechin gallate with collagen leads to rapid wound healing activity (30).

\section{Antimicrobial activity of Triphala}

Triphala churna also has antibacterial properties against a variety of infections. Its extracts in acetone, ethanol, and methanol have a significant antibacterial potential against a wide range of bacteria, including Staphylococcus epidermidis, Staphylococcus aureus, Pseudomonas, and E. coli. Triphala and its constituents had an antibiotic impact on both grampositive and gram-negative bacteria, implying that active phytochemicals entered the bacterial cells through both walls. Triphala kwatha churna is antimicrobial and effective against a variety of bacterial infections. Triphala has antibacterial efficacy against pathogens such as Salmonella, Staphylococcus aureus, Pseudomonas, E. coli, and Bacillus isolated from worker and student wounds. Triphala is beneficial against enteric bacterial infections as well as enterococci. It has demonstrated broad-spectrum antibacterial efficacy against several resistant bacterial isolates. Triphala and its components have also been shown to be beneficial against harmful microorganisms in humans (31).

\section{Analgesic, antipyretic and ulcerogenic activities of Triphala}

Triphala's analgesic, antipyretic, and ulcerogenic properties were compared with the nonsteroidal anti-inflammatory agent, Indomethacin in rat experimental models, and it was discovered that Triphala exhibited outstanding analgesic and antipyretic effects at both dose levels, with minimal gastrointestinal harm. In a recent study, the anti-ulcer efficacy of polyherbal formulation was investigated in rats with aspirin and pyloric ligation caused stomach ulcers (32).

\section{Triphala as an immune modulator.}

Triphala has immunomodulatory effects when assessed using the carbon clearance test and the Delayed-Type Hypersensitivity (DTH) reaction. Triphala's immunomodulatory properties can be attributed to flavonoids, alkaloids, tannins, saponins, glycosides, and phenolic chemicals (32). Furthermore, studies have validated several potential uses of Triphala, including free radical scavenging, antioxidant, immune-modulating, appetite stimulation, gastric hyperacidity reduction, dental caries prevention, antipyretic, analgesic, antibacterial, antimutagenic, antistress, wound healing, anti-cariogenic, hypoglycemic, anti-inflammatory, anticancer, hepatoprotective, adaptogenic, and chemoprotective (33). Triphala may also enhance appropriate digestion and absorption of food, improve circulation, relax bile ducts, lower serum cholesterol levels, prevent immunosenescence, maintain endocrine system balance, and increase red blood cell and hemoglobin formation (28).

\section{Anti-inflammatory effects of Triphala}

Chronic inflammation is harmful and affects most major chronic health disorders. Triphala is effective as an anti-inflammatory drug. In one study, Triphala outperformed or was similar to normal medication treatment in several biochemical measures of inflammation (34,35). Triphala also decreased inflammatory markers, as well as bone and cartilage deterioration, in arthritic rats. Triphala extract was found to be much more effective than indomethacin, a nonsteroidal anti-inflammatory medication, in alleviating arthritic and inflammatory symptoms $(28,30)$. 
Table 1. Samhita and Nighantu (36)

Samhita and Nighantu

Varga

\begin{tabular}{|c|c|c|}
\hline & $\begin{array}{l}\text { Samhita and } \\
\text { Nighantu }\end{array}$ & Varga \\
\hline 1 & $\begin{array}{l}\text { Charaka } \\
\text { Samhita }\end{array}$ & $\begin{array}{l}\text { Virechanopaga Mahakashaya, } \\
\text { Jwarahara Mahakashaya, } \\
\text { Kashaya skandha }\end{array}$ \\
\hline 2 & Susruta Samhita & $\begin{array}{l}\text { Muskadi gana, Parushkadi gana, } \\
\text { Mustadi gana, } \\
\text { Triphala gana, Amlakyadi gana, } \\
\text { Kashaya skandha }\end{array}$ \\
\hline 3 & Astanga Hridya & $\begin{array}{l}\text { Virechana gana, Parushkadi } \\
\text { gana, Muskadi gana Mustadi } \\
\text { gana }\end{array}$ \\
\hline 4 & $\begin{array}{l}\text { Astanga } \\
\text { Sangrah }\end{array}$ & $\begin{array}{l}\text { Virechanopayogi Dravya, } \\
\text { Jwarahara Mahakashaya } \\
\text { Parushkadi gana, Muskadi gana, } \\
\text { Mustadi gana }\end{array}$ \\
\hline 5 & $\begin{array}{l}\text { Dhanvantari } \\
\text { Nighantu }\end{array}$ & $\begin{array}{l}\text { Guduchyadi gana, Mishrakadi } \\
\text { varga }\end{array}$ \\
\hline 6 & $\begin{array}{l}\text { Shodhala } \\
\text { Nighantu }\end{array}$ & Guduchyadi gana \\
\hline 7 & $\begin{array}{l}\text { Kaidev } \\
\text { Nighantu }\end{array}$ & Aushadhi varga \\
\hline 8 & $\begin{array}{l}\text { Madanpal } \\
\text { Nighantu }\end{array}$ & Abhyadi varga \\
\hline 9 & Raj Nighantu & $\begin{array}{l}\text { Mishrakadi varga, Audhabhida } \\
\text { varga }\end{array}$ \\
\hline 10 & $\begin{array}{l}\text { Bhavaprakash } \\
\text { Nighantu }\end{array}$ & Haritkyadi Nighantu \\
\hline 11 & Priya Nighantu & Haritkyadi Nighantu \\
\hline 12 & $\begin{array}{l}\text { Nighantu } \\
\text { Adarsh }\end{array}$ & Haritkyadi Nighantu \\
\hline 13 & $\begin{array}{l}\text { Dravya guna } \\
\text { Vigyan }\end{array}$ & Rasayana varga, Chednadi varga \\
\hline
\end{tabular}

\section{Discussion}

Following a review of the drug's qualities, it is discovered that Tannin's mode of anti-microbial action may be related to its ability to inactivate microbial adhesins, enzymes, and cell envelope transport proteins, which can treat or prevent a range of diseases. Surfaceexposed adhesins, cell wall polypeptides, and membrane-bound enzymes are the most likely targets of quines in the microbial cell (37). Flavones, flavonoids, and flavonols are known to be generated by plants in response to microbial infection and potent antimicrobial compounds against a wide range of bacteria (18). Gallic acid has also been demonstrated to have hepatoprotective and antioxidant properties (21). Triphala has the potential in oral care to reduce the number of oral bacteria, tooth plaque, and gingivitis in human subjects by combining vitamin $\mathrm{C}$ and bioflavonoid. Triphala reduces stress, aids wound healing due to the incorporation of collagen sponges, and has analgesic, antipyretic, and ulcerogenic properties. It is more likely that antiseptic gargles and Gandusha aid in the maintenance and healing of Aphthous Ulcer. It has both local and systemic effects, however, it is most noticeable in local activities such as Gandusha. Several ulcers in the previous month were reported as oral ulcer activity. If there were no ulcers, this was scored zero; otherwise, it was scored one if the number of ulcers was greater than or equal to one. A $100-\mathrm{mm}$ line with extreme values at either end. Patients must mark the level of their pain on a line (28). Triphala has immunomodulatory qualities as well as Shothahara (anti-inflammatory) and Ropana (healing) characteristics, as well as anti-oxidant properties (33).

\section{Conclusion}

Triphala is the right medicine with therapeutic properties given to the world by Ayurveda. A wide range of human disorders can be treated with minimal negative effects. Triphala kwatha gandusha maintains and heals Aphthous ulcer oropharyngeal illness by increasing mechanical pressure inside the oral cavity, stimulating salivary glands, increasing vascular permeability, maintaining oral $\mathrm{pH}$, and its antiinflammatory, anti-oxidant, and wound healing qualities.

\section{References}

1. Harnoorkar VN. Effect of Triphala kashaya gandoosha \& sheetali pranayama in Mukhapaka w.s.r to recurrent aphthous stomatitis - a case study. International Journal of AYUSH. 2018;7(4):11-8.

2. Mamgain R, Gupta M, Mamgain P, Verma S, Pruthi $\mathrm{D}$, Kandwal A, et al. The efficacy of an ayurvedic preparation of yashtimadhu (Glycyrrhiza glabra) on radiation-induced mucositis in head-and-neck cancer patients: A pilot study. Journal of Cancer Research and Therapeutics. 2020;16(3):458.

3. Queiroz SIML, Silva MVA da, Medeiros AMC de, Oliveira PT de, Gurgel BC de V, Silveira ÉJD da. Recurrent aphthous ulceration: an epidemiological study of etiological factors, treatment and differential diagnosis. Anais Brasileiros de Dermatologia. 2018;93(3):341-6.

4. Roopa L, Shamsha Fiaz, Dingari Laksmana Chary, Bali Yogitha M. Role of Gandusha in Pittaja Mukhapaka (Aphthous Ulcer) -A Randomized Controlled Trial. International Journal of Ayurveda and Pharma Research. 2019;7(2):7-18.

5. Peterson CT, Denniston K, Chopra D. Therapeutic Uses of Triphala in Ayurvedic Medicine. The Journal of Alternative and Complementary Medicine. 2017 Aug;23(8):607-14.

6. Hosamani RB. a Review on Gandusha: an Ayurvedic Therapeutic Procedure for Oral Disorders. International Ayurvedic Medical Journal. 2017;1(6): 746-754.

7. Deswal H, Singh Y, H.S.Grover, Bhardwaj A, Shalu Verma. Curative Effect of Triphala in Medical and Dental Sciences : A Scientific Review. Innovare Journal of Health Sciences. 2016;4(2 SE):1-4.

8. Das AK, Islam MN, Faruk MO, Ashaduzzaman M, Dungani R. Review on tannins: Extraction processes, applications and possibilities. South African Journal of Botany. 2020;135:58-70. https:// doi.org/10.1016/j.sajb.2020.08.008

9. Ghahri S, Pizzi A. Improving soy-based adhesives for wood particleboard by tannins addition. Wood Science and Technology. 2018;52(1):261-79.

10. Chang Z, Zhang Q, Liang W, Zhou K, Jian P, She $\mathrm{G}$, et al. A Comprehensive Review of the Structure 
Elucidation of Tannins from Terminalia Linn. Evidence-Based Complementary and Alternative Medicine. 2019;2019:1-26.

11. Giovando S, Koch G, Romagnoli M, Paul D, Vinciguerra V, Tamantini S, et al. Spectrotopochemical investigation of the location of polyphenolic extractives (tannins) in chestnut wood structure and ultrastructure. Industrial Crops and Products. 2019;141:111767.

12. Prakash S, Shelke A. Role of Triphala in dentistry. Journal of Indian Society of Periodontology. 2014;18(2):132.

13. Khanbabaee K, van Ree T. Tannins: Classification and definition. Natural Product Reports. 2001; 18: 641-9.

14. Jali BR. A Mini-Review: Quinones and their Derivatives for Selective and Specific Detection of Specific Cations. Biointerface Research in Applied Chemistry. 2020;11(4):11679-99.

15. El-Najjar N, Gali-Muhtasib H, Ketola RA, Vuorela P, Urtti A, Vuorela H. The chemical and biological activities of quinones: Overview and implications in analytical detection. Phytochemistry Reviews. 2011;10(3):353-70.

16. Madeo J, Zubair A, Marianne F. A review on the role of quinones in renal disorders. SpringerPlus. 2013;2(1):139.

17. Panche AN, Diwan AD, Chandra SR. Flavonoids: an overview. Journal of Nutritional Science. 2016;5:e47.

18. Mierziak J, Kostyn K, Kulma A. Flavonoids as Important Molecules of Plant Interactions with the Environment. 2014;16240-65.

19. Graf BA, Milbury PE, Blumberg JB. Flavonols, flavones, flavanones, and human health: Epidemiological evidence. Journal of Medicinal Food. 2005; 8: 281-90.

20. Manish Pal S, Avneet G, Siddhraj SS. Gallic Acid: Pharmacogical Promising Lead Molecule: A Review. International Journal of Pharmacognosy and Phytochemical Research. 2018;10(4).

21. Bustami A, Sopiah P, Muharam R, Wibowo H. Effects of Gallic Acid and Its Derivates on Inflammatory Regulation of Endometriotic Primary Cultures: Study on NF-kB mRNA Expression and IL-6 Secretion. Biomedical and Pharmacology Journal. 2018;11(3):1479-84.

22. Kahkeshani N, Farzaei F, Fotouhi M, Alavi SS, Bahramsoltani R, Naseri R, et al. Pharmacological effects of gallic acid in health and disease: A mechanistic review. Iranian Journal of Basic Medical Sciences. 2019;22(3):225-37.

23. Chambial S, Dwivedi S, Shukla KK, John PJ, Sharma P. Vitamin C in Disease Prevention and Cure: An Overview. Indian Journal of Clinical Biochemistry. 2013 Oct 1;28(4):314-28.

24. Khakoni Walingo M. Role of Vitamin C (Ascorbic Acid) on Human Health-a Review. African Journal of Food Agriculture and Nutritional Development. 2005;5(1).

25. Lykkesfeldt J, Tveden-Nyborg P. The Pharmacokinetics of Vitamin C. Nutrients. 2019;11(10):2412.

26. Grosso G, Bei R, Mistretta A, Marventano S, Calabrese G, Masuelli L, et al. Effects of vitamin C on health: A review of evidence. Frontiers in Bioscience. 2013;18(3):1017-29.

27. Kumar NS, Nair AS, Nair AM, Murali M. Pharmacological and therapeutic effects of Triphala - A literature review. Journal of Pharmacognosy and Phytochemistry JPP. 2016;23(53):23-7.

28. Revathi S, Gopal V, Jeyabalan G. Triphala-The Sanctifying Medicine to Human Domain: A Review. Der Pharmacia Lettre. 2018;10(9):71-89.

29. Kalpana S. Wakode, Nikita Sadashiv Deshmukh. A review literature - gandusha in mukharogas. World Journal of Pharmaceutical and Medical Research. 2019;5(11):66-8.

30. Vinitha V Nair, Rajashekhara N KBM. Clinical evaluation of Ashvattha (Ficus religiosa Linn.) in Mukhapaka with special reference to an aphthous ulcer. 2015;1(3):77-80.

31. Salma U, Sinha A, Basha NFA, Shariff A. Triphala: The Mystical Herb and Its Role in Dentistry. International Journal of Contemporary Medical Research. 2020;7(5):17-21.

32. Meghana, Dangar Rajeev GD. A Clinical Study on the Management of Mukhapaka with Special Reference to Stomatitis With Patoladi Kwath Gandusha. European Journal of Biomedical and Pharmaceutical Sciences. 2019;6(7):421-9.

33. Chouhan B, Kumawat RC, Kotecha M, Ramamurthy A, Nathani S. Triphala: A Comprehensive Ayurvedic Review. International Journal Of Research In Ayurveda \& Pharmacy. 2013 Aug 26;4(4):612-7.

34. Baliga MS. Triphala, Ayurvedic Formulation for Treating and Preventing Cancer: A Review. The Journal of Alternative and Complementary Medicine. 2010 Dec;16(12):1301-8.

35. Sireeratawong S, Jaijoy K, Soonthornchareonnon N. Evaluation of anti-inflammatory and antinociceptive activity of Triphala recipe. African Journal of Traditional, Complementary and Alternative Medicines. 2013;10(2):246-50.

36. Chaudhary SP. an Ayurvedic Review of Ashwagandha From Samhitha and Nighantus. World Journal of Pharmaceutical Research. 2015;4(10):2736-45.

37. Gowda D V., Muguli G, Rangesh PR, Deshpande RD. Phytochemical and pharmacological actions of Triphala: Ayurvedic formulation - A review. International Journal of Pharmaceutical Sciences Review and Research. 2012;15(2):61-5. 